\title{
Iron ore tailings in the production of cement tiles: a value analysis on building sustainability
}

Rejeito de barragem de minério de ferro na produção de ladrilhos hidráulicos: uma análise de valor para sustentabilidade de edificações

\author{
Wanna Carvalho Fontes \\ Giovanni Gonçalves Fontes \\ Ellen Cristine Pinto Costa \\ Julia Castro Mendes \\ Guilherme Jorge Brigolini Silva \\ Ricardo André Fiorotti Peixoto
}

\begin{abstract}
$\mathbf{T}$

he present work discloses the development of a sustainable cement tile (SCT) produced with Iron Ore Tailings from tailings dams (IOT). Initially, technical evaluation and environmental analysis of IOT were performed through physical, chemical and morphological

characterisation, leaching and dissolution tests. Its feasibility as a pigment was also investigated. Subsequently, the value analysis was performed, starting from an empathy map to a study on environmental, social and emotional values in the relationship between people and product. As result, the IOT presented fine, crystalline particles, no toxicity, and is technically feasible to be employed as filler, aggregate and pigment in the production of SCT. The colour layer of the SCT presented more homogeneous colour and less pores than conventional ones. Therefore, the design of the SCT was developed, incorporating intangible values such as: environmental ideology, local identity and social expression. In this sense, the present work seeks to assist in the decision-making process involving IOT as construction material.
\end{abstract}

1 Wanna Carvalho Fontes IUniversidade Federal de Ouro Preto Ouro Preto - MG - Brasil

${ }^{2}$ Giovanni Gonçalves Fontes ${ }^{2}$ Faculdade Dom Luciano Mendes Mariana - MG - Brasil

${ }^{3}$ Ellen Cristine Pinto Costa ${ }^{3}$ Universidade Federal de Ouro Preto Ouro Preto - MG - Brasil

${ }^{4}$ Julia Castro Mendes ${ }^{4}$ Universidade Federal de Ouro Preto Ouro Preto - MG - Brasil

${ }^{5}$ Guilherme Jorge Brigolini Silva ${ }^{5}$ Universidade Federal de Ouro Preto Ouro Preto - MG - Brasil

${ }^{6}$ Ricardo André Fiorotti Peixoto ${ }^{6}$ Universidade Federal de Ouro Preto Ouro Preto - MG - Brasil

Recebido em 31/07/17 Aceito em 23/02/18
Keywords: Sustainable building materials. Cement tiles. Iron ore tailings. Value analysis.

\section{Resumo}

O presente trabalho abrange o desenvolvimento de ladrilho hidráulico sustentável (LHS) produzido com rejeitos de barragem de minério de ferro (RBMF). Inicialmente, a avaliação técnica e a análise ambiental do RBMF foram realizadas através de testes de caracterização física, química e morfológica, lixiviação e dissolução. Sua viabilidade como pigmento também foi investigada. Posteriormente, a análise de valor foi realizada, partindo de um mapa de empatia até o estudo sobre valores ambientais, sociais e emocionais na relação entre pessoas e produtos. Como resultado, o RBMF se apresentou como partículas finas, cristalinas, sem toxicidade, sendo tecnicamente viável para ser empregado como filer, agregado e pigmento na produção de LHS. A camada de cor do LHS apresentou cores mais homogêneas e menos poros do que as convencionais. Assim, o projeto do LHS foi desenvolvido, incorporando valores intangíveis como: ideologia ambiental, identidade local e expressão social. Nesse sentido, o presente trabalho busca ajudar nas tomadas de decisão envolvendo RBMF como material de construção.

Palavras-chave: Materiais de construção sustentáveis. Ladrilhos hidráulicos. Rejeitos de barragem de minério de ferro. Análise de valor. 


\section{Introduction}

Brazil is currently one of the world leaders in exploitation of mineral resources. Billions of tons of metal ores are mined in the country every year, and millions of tons of tailings and wastes are disposed of, mainly in tailing dams (FIGUEIRÔA, 2014; INSTITUTO..., 2015). Since the beginning of the $18^{\text {th }}$ century, the mining industry has been concentrated in the state of Minas Gerais, responsible for the largest production of iron ore, gold, zinc and niobium of the country (IBRAM, 2014). In Minas Gerais are accounted 445 of the 663 tailings dams in Brazil (FUNDAÇÃO..., 2014). As a result of the high volumes of production and poor management of residues, a dam recently collapsed in Minas Gerais, leading to the release of 62 million cubic meters of iron ore tailings (IOT), several casualties, and an expressive impact on the ecosystems over a $100 \mathrm{~km}$ radius (G1, 2015). Mining operations must be conducted in sustainable, economically feasible and socially acceptable manner (FRANKS et al., 2011). Waste management technologies that offer improved environmental and social performance should be preferentially adopted; including opportunities for the reuse of tailings (EDRAKI et al., 2014).

The use of tailings in construction materials implies in a significant reduction in the overall carbon footprint of a building; it also mitigates the consumption of natural resources and the impacts associated with their production (PAPPU; SAXENA; ASOLEKAR, 2007; PASSUELO et al., 2014). In this sense, as examples, Fontes et al. (2016), Shettimma et al. (2016), Zhao, Fan and Sun (2016), Ma et al. (2016) and Yellishetty et al. (2008) have successfully used it as aggregate; Pereira and Bernardin (2012) as colorant; Duan et al. (2016), Cheng et al. (2016) as geopolymer and binder. Iron ore tailings are mainly composed by iron oxides, silica and alumina, resulting in a fine, dense, stable and crystalline material (BASTOS et al., 2016), technically feasible to be employed in civil construction.

Regarding its behaviour on the cement matrix, in a previous work, Fontes et al. (2016), tested mortars comprising IOT in full replacement of natural aggregates. The mortars with IOT reached compressive and flexural strengths superior than the conventional ones. In a similar work, matrices developed by Sant'Ana Filho et al. (2016), with replacement of fine aggregate by IOT in proportions up to $80 \%$, showed lower water absorption and more resistance to abrasion than their conventional counterparts.
Therefore, in order to contribute to the reduction of the environmental and social impacts of the disposal of IOT, the present work proposes a novel application for it - as both aggregate and pigment in sustainable cement tiles (SCT).

\section{Cement tiles}

Cement tiles are cement-based composite plates with high abrasion resistance used in walls and floors, indoor and outdoor. They have a flat surface, textured or embossed, coloured or not, and are usually square shaped (ASSOCIAÇÃO..., 2010).

Historically, by the fourth century, the tiles were made up of pieces of coloured stones, with symbolic function to express the art and religion of the territories dominated by the Byzantine Empire (WAMZER, 2011). From the second half of the nineteenth century on, the composition of the tiles evolved to Portland cement composites, pressed, dried and cured by immersion in water (WAMZER, 2011). This new constitution contributed to the technological gain of the cement tiles, hence motivating its large-scale adoption around the world.

Unvalued around the 1950s, due to competition with ceramic tiles, since 1980, architects, designers and decorators have begun again to appreciate coatings with cement tiles (CATOIA, 2007). This is a reflex of the current trend to seek traces of memory in the past, in order to enhance value through intangible aspects such as nostalgia and emotion. The revival of cement tiles allowed for customized designs, and for creating composition with other materials (CATOIA, 2007).

A cement tile is divided in two layers. The wear/colour layer, in the surface, is approximately $3-5 \mathrm{~mm}$ thick, and comprises a fine mixture of white cement (WC), crushed white marble (CWM) or fine sand $(0.075$ to $0.6 \mathrm{~mm})$ and conventional pigments $(\mathrm{CP})$. The quality of this layer provides the abrasion resistance, the colour and brightness of the tile. The base layer, approximately $20 \mathrm{~mm}$ thick, consists of a mortar of cement and medium sand $(0.6$ to $1.18 \mathrm{~mm})$, and provides the mechanical strength. Both layers are compressed into one single tile by a specific set of moulds and a hydraulic press.

The manufacture of cement tiles in Brazil is mostly scattered among craft shops in the Southeast region, where most of the population - and tailings dams - are located. The initial investment is relatively low, as is the producer's educational

396 Fontes, W. C.; Fontes, G. G.; Costa, E. C. P.; Mendes, J. C.; Silva, G. J. B. Peixoto, R. A. F. 
requirements. The incorporation of IOT does not require adaptation in the production method, based on manual hydraulic press; that is, no energy is required for either acquiring equipment or operating it.

To achieve a good relationship between product and user, the study of interfaces is critical to the market. It involves a value analysis through the integration of technical, production, and administrative sectors, as well as environmental, social and emotional factors. Therefore, by incorporating intangible attributes, the development of more effective products is attained - that is - products that meet the intended use, as well as other consumer's expectations (GONTIJO, 2008).

\section{Value analysis}

Value Analysis consists in the representation of technological evolution, given its approach from the birth of a need to its final conception (VARGAS, 2013; PEREIRA FILHO, 1994). It is a systematic application of techniques to identify the main aspects of a product or a component and to provide the desired function at the minimum cost. Consequently, it enables analysing the return on investment of a new product and thus allows for the decision to whether continue the project or not. Within the economic sphere, the real value of a product, process or system comprises the combination of specific values and represents the degree of acceptance by the customer, directly depending on local and temporal conditions (VARGAS, 2013).

Regarding the Methodology of Value (CSILLAG, 1995), the economic value is divided in:

(a) use value $(\mathrm{Vu})$ : monetary measure of the qualities related to the performance of use;

(b) esteem value (Ve): monetary measure of the properties that make its possession desirable; (c) cost value $(\mathrm{Vc})$ : monetary measure to produce or obtain a product; and

(d) exchange value $(\mathrm{Vx})$ : monetary measure that enables the exchange for other goods.

Based on the values described, there are two ways of analysing the exchange value of a product. For the consumer, by adding the values of use and esteem (Eq. 1):

$V x=V u+V e$

For the producer, as the sum of the cost and a differential $(\Delta V)$, considered the profit (Eq. 2):

$V x=V c+\Delta V$

Eq. 2

Therefore, combining both equations (Eq. 3):

$V u+V e=V c+\Delta V$

Through this relationship, it is possible to infer that the higher the use value $(\mathrm{Vu})$ and esteem $(\mathrm{Ve})$ and the lower the cost value $(\mathrm{Vc})$, the greater the profit made on a product $(\Delta \mathrm{V})$.

\section{Emotional/Esteem Value}

Emotion is closely linked to the relationship that people have with a product. Jordan(1999) presented a hierarchy of needs, considering that people demonstrate their experience with the product when they relate to it. This experience covers aspects of utility, functionality, ease of use, as well as sensory conceptions, as shown in Figure 1.

Figure 1 shows the pleasure at the top of the hierarchy of needs, representing the degree of pleasantness of people in interaction with objects. Therefore, when dealing with product design, the engineer/architect/designer can start by specifying the desired emotion as a result, such as social expression, environmental ideology, nostalgia, or sensory pleasures. Only then the professional evaluates the usability parameters, technical and safety aspects, considering whether it meets the required performance.

Figure 1- Hierarchy of the user's needs for products

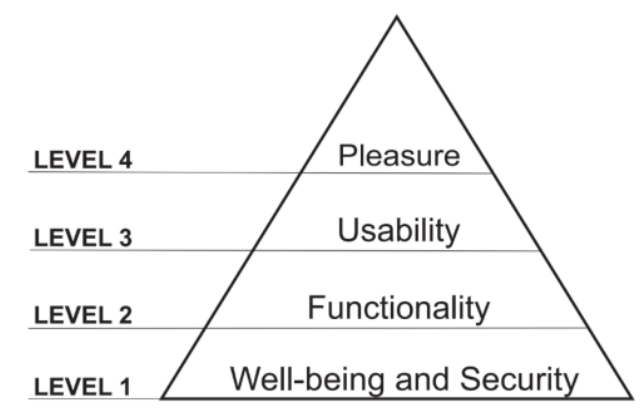

Source: adapted from Jordan (1999). 
The esteem value of a product can be established by features that confer it beauty, prestige and admiration considering its aesthetic values, as well as connection and affection towards their symbolic values.

For a better understanding of the esteem value it is necessary to subdivide it in aesthetic value and symbolic value. The aesthetic value is related to the semantics of the product, which consists of a suitable visual appearance its function. Thus, with respect to colours, shapes, textures and backgrounds, which include automatic emotional responses related to the first contact with the product (CREUSEN; SCHOORMANS, 2005). According to Kissmetrics (2010), 93\% of consumers consider the appearance of the goods when shopping and $85 \%$ say the colour is the main reason they purchase a particular product.

In turn, the symbolic value of a product comprises the conception of memory and self-image, based on intrinsic and social values of each person (MIRANDA; CÂMARA, 2010). Therefore, the symbolic functions are associated with sociocultural relations, obtained through the social, historical and technological context of a country or region.

The reaffirmation of the local identity in products, to the extent that it establishes links and connections, creates a benchmark of authenticity in the midst of mass production and homogeneity that have prevailed since globalization. In this sense, one must unite characteristic elements of a culture: i.e. the fauna, flora, architecture, topography, religion, among others (MORAES, 2008).

In this sense, one notable example is the Lucky Iron Fish TM. In order to provide dietary supplementation of iron to underprivileged families affected by iron-deficiency anaemia in Cambodia, a group of researchers distributed a rectangular iron bar for cooking. However, the women were reluctant to use the chunk of iron in the cooking pan. The solution came through design enhancement: the previous iron bars were replaced by fish-shaped iron ingots, which carry strong cultural and historical bonds to the population. As a result, the iron fish were received more positively by the villagers and led to immediate increases in blood iron levels among them. In addition, the iron fish are cast from recycled metal, and employ the Cambodian community in the production line. Since the beginning of this project, the research group has delivered over 82,000 iron fish around the world (LUCKY..., 2016).

\section{Social value}

According to the Brazilian Institute of Mining (INSTITUTO..., 2013), the strengthening of accountability and transparency is directly related to understanding of the mining industry's contributions to the development of the country. According to a research conducted by the Ethos Corporate Social Responsibility Indicators concerning the perception of Brazilian consumers, $86 \%$ of respondents would increase their respect for a company if it became partner of a nongovernmental organization or charity institution, with the purpose of solving social problems (RUSCHEL; ROSE, 2005).

Therefore, the structure of the economy attributes a particular social role to goods. It is believed that the product carries an inexplicable power over the buyer, in order to satisfy their desires for attraction, ideology, identity, social expression, among others (LEDOUX, 1998).

\section{Environmental value}

Since the 1980s, intangible aspects such as image and corporate culture of companies have become their greatest asset (ESTY; WINSTON, 2009). According to Willard (2002), a company, when employing principles of social and environmental sustainability, has the potential to increase profits by up to $38 \%$, its market value by $12 \%$ and productivity by up to $8 \%$, due to the reduction of production costs and expenses, such as energy, water, raw materials, among others

In this scenario, customer demand for sustainable construction materials has also been boosted due to greater environmental awareness. Increased recognition of climate change is changing priorities as people remodel the way they live to reduce the impacts of their daily life on the environment. In fact, customers are seeking innovative solutions that would improve their quality of life, reduce their energy-related costs, while being environmentally-friendly (OBSERVATORY, 2014).

In conclusion, an investment in the intangibility of the product, i.e. the adoption of factors such as novelty and sustainability, is directly related to improvement in the tangibility of sales. In this sense, this work evaluates both the technical and intangible aspects of a SCT produced with IOT, aiming to develop the best possible building solution regarding design and material. Therefore, we seek to obtain an economically feasible product, while contributing to the reduction of the social and environmental impact of tailings dams.

398 Fontes, W. C.; Fontes, G. G.; Costa, E. C. P.; Mendes, J. C.; Silva, G. J. B. Peixoto, R. A. F. 


\section{Methodology}

Initially, an experimental program was undertaken to evaluate the technical and environmental feasibility of the use of IOT as aggregate and pigment in the production of SCT. Secondly, an empathy map was drawn based on the profile of one professional in interior design and one potential consumer seeking to identify all significant variables in the value analysis. Finally, an exploratory investigation was conducted to identify and apply intangible value on this product. Intangible aspects of this product were assessed through strategies proposed by the service design, in environmental, social and emotional levels. As a result of these studies, the SCT was developed.

\section{Technical feasibility}

The proposed product is a sustainable cement tile (SCT), intended for use as floor tile, indoors and outdoors. In this work, IOT was employed as aggregate in the base layer and pigment in the colour layer. The physical characterisation of IOT, CWM and sand comprised: particle size distribution by sieving and laser diffraction (Bettersize 2000 equipment), bulk specific gravity and apparent specific gravity. Tests were performed according to Brazilian standards NBR 7217 (ABNT, 1987), NBR NM 45(ABNT, 2006) and NBR NM 53 (ABNT, 2003).

A Coleman Optical Microscope and a Scanning Electron Microscope (SEM), were used to investigate the microstructure of the tailings. Experiments and analyses involving electron microscopy were performed in the Nanolab Electronic Microscopy Laboratory, at the Redemat, UFOP; and the Materials Characterisation Laboratory, at CEFET, MG, Brazil.

Chemical characterization was carried out by a semi-quantitative energy dispersive X-ray fluorescence (XRF) in a PANalytical Epsilon 3X equipment. The DRX was carried out on a D2 PHASER from Bruker at Nanolab, Redemat, Federal University of OuroPreto. The equipment operated with $\mathrm{CuK} \alpha$ radiation, $30 \mathrm{kV}$ tension, 30 $\mathrm{mA}$ current intensity, angular velocity equal to $0.02^{\circ}, 0.8$-second step, and angular range between $5^{\circ}$ and $70^{\circ}$. The analysis and refinement of results were performed using the Rietveld method, on aX'Pert High Score Plus Panalytical software, aided by the Crystallography Open Database (COD) database of crystal structures. Fluorite (CaF2), brand VETEC, was used as internal standard, added in proportion of $10 \%$ to the IOT mass. The samples were weighed to a precision of four decimal places and homogenized in porcelain mortar.

According to the Brazilian standard, NBR 7211 (ABNT, 2009), the aggregate for cement-based composites must be an inorganic, crystalline and stable material. They must not present hazardous chemical substances, such as chlorites and sulphates (in concentrations above $0.2 \%$ and $0.1 \%$ respectively), or substances that may affect the hydration of the cement (ABNT, 2009). Preferably, they must attend to optimum particle size distribution zones, i.e. the maximum content of material passing the \#8 sieve $(2.36 \mathrm{~mm})$ must fall between $10 \%$ and $20 \%$ (ABNT, 2009). However, the standard states that materials with different particle size distributions may still be used, given that their applicability is proven. This is achieved by the morphological and chemical analysis.

\section{Environmental feasibility}

Leaching and dissolution tests were performed to assess the level of contamination of the elements in the sample, according to standards NBR 10005 (ABNT, 2004a) and NBR 10006 (ABNT, 2004b). These tests seek to reproduce the natural phenomena of carrier, dilution and dissolution that occur when water passes through a residue.

For the leaching test, the Brazilian Standard prescribes the jar-test equipment for continuous stirring; no definite speed; and waste/deionised water ratio of $1: 16$. This standard uses $0.5 \mathrm{~N}$ acetic acid as $\mathrm{pH}$ control $(\mathrm{pH}=5)$. In turn, the dissolution test uses a waste/deionised water ratio of 4:1; 5-min stir; and 7-day rest. The leached and solubilised extracts are filtered in a $0.45 \mu \mathrm{m}$ porous media. Subsequently, they are chemically analysed to identify several toxic organic and inorganic compounds.

According to the concentration of the substances in the leachate and solubilised extracts, the residue is classified, following the prescribed limits in standard NBR 10004 (ABNT, 2004c). Solid materials can be classified according to NBR 10004 (ABNT, 2004c) as Class I - dangerous, or Class II - non-dangerous. In addition, Class II is divided into Class II-A: non-inert and Class II-B: inert. In total, the tests evaluate 35 parameters, such as the $\mathrm{pH}$, the concentration of arsenic, barium, cadmium, lead, sulphates, mercury, organic compounds, among others. The classification is based on the parameters that the samples exceed the stipulated limits. 


\section{Feasibility as pigment}

The inorganic pigments used in cement tiles are fine particles, generally insoluble in water (LEE; LEE; YU, 2003). They are usually comprised of iron oxide and chromium oxide; with proportions that vary according to the desired colour. In order to produce stable and aesthetically pleasing pigments, IOT was employed in 2 forms: in natura and fired. In both cases, the materials were ovendried.

To obtain the fired IOT, the waste was initially segregated in its main components: iron ore, sand and clay; through a process performed by an outsourced company. This process involves drying, milling, density separation and magnetic separation without the use of water (PEIXOTO; BARROS; OLIVEIRA, 2014). It should also be noted that the segregation process makes it possible to recover iron ore from IOT, a material of greater economic interest.

The clay fraction was adopted in the present work. This fraction contains a higher concentration of iron oxide in the hematite and goethite phases than the raw IOT (ANDRADE, 2014). Furthermore, the sinter and calcination processes promote the conversion of goethite into hematite by dehydroxylation and, consequently, improves the pigmentation capacity of the material (TAVARES,
2012). For the preparation of the pigment, the clay from the IOT was fired at $950{ }^{\circ} \mathrm{C}$ for $120 \mathrm{~min}$ in a muffle furnace (brand Jung JB3013), with temperature step of $3{ }^{\circ} \mathrm{C} / \mathrm{min}$. Subsequently, it was grinded in a planetary ball mill (brand Retsch PM 100) for $10 \mathrm{~min}$ in rotation of $400 \mathrm{rpm}$. This fraction was adopted as pigment (P-IOT).

The SCT were fabricated according to the conventional technique called "Pastinha", which refers to the high fluidity of the mortar in the colour layer. Specimens $5 \times 5 \times 2 \mathrm{~cm}$ were moulded in proportions 2:1 - white cement (WC):aggregate in mass (Figure 2). Two types of aggregate were used: crushed white marble (CWM) and IOT in natura. On specimens with only CWM, contents of $5 \%$ and $10 \%$ of pigments were added conventional and P-IOT. The conventional pigment $(\mathrm{CP})$ is a brown inorganic synthetic material suitable for use in cement-based composites, produced by Lanxess and purchased directly on the market.

In all mixtures, $70 \mathrm{ml}$ of water was used (water/cement factor of 0.7). In total, nine mixtures were proposed using WC, CWM, CP, IOT and CIOT both as aggregate and pigment, as shown in Table 1. Mixtures T10 and T11 are dual colour, $\mathrm{T} 1+\mathrm{T} 4$ and $\mathrm{T} 1+\mathrm{T} 8$ respectively, developed seeking to access the possible mixing of colours.

Figure 2 - Sample of the colour layer with IOT as aggregate, for pigment evaluation

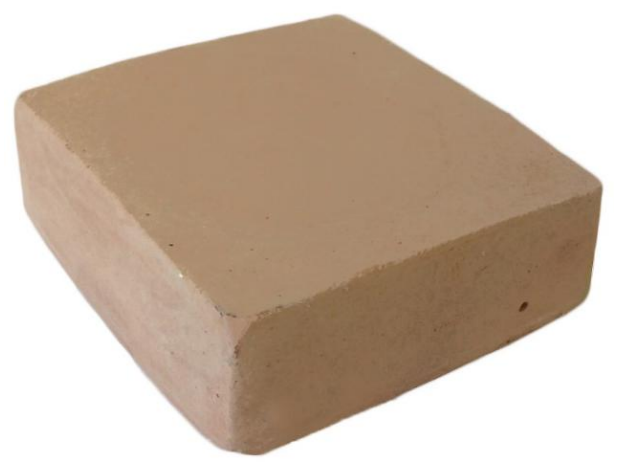

Table 1 - Mixtures developed for the colour layer

\begin{tabular}{l|c|c|c|c|c}
\hline & WC $(\mathbf{g})$ & CWM (g) & CP (g) & IOT (g) & P-IOT (g) \\
\hline T1 - CWM & 100 & 50 & & & \\
T2 - 50\% CWM + 50\% IOT & 100 & 25 & & 25 & \\
T3 -IOT & 100 & & & 50 & \\
T4 - CWM + 5\% CP & 100 & 50 & 5 & & \\
T5 - CWM + 10\% CP & 100 & 50 & 10 & & \\
T6 - CWM + 5\% IOT & 100 & 50 & & 5 & \\
T7 - CWM + 10\% IOT & 100 & 50 & & 10 & \\
T8 - CWM + 5\% P-IOT & 100 & 50 & & & 5 \\
T9 - CWM + 10\% P-IOT & 100 & 50 & & & 10 \\
\hline
\end{tabular}

400 Fontes, W. C.; Fontes, G. G.; Costa, E. C. P.; Mendes, J. C.; Silva, G. J. B. Peixoto, R. A. F. 
The colour range, surface quality and proportion of IOT as pigment were evaluated through visual inspection. As prescribed by Brazilian standard for cement tiles, NBR 9457 (ABNT, 2013), the material must present aspects such as homogeneity of colour, sharp edges, no cracks, visible burrs or flaws.

\section{Value analysis}

According to the Methodology of Value (CSILLAG, 1995), when considering the use of IOT in the production of SCT, it is assumed to generate an increase in the profit of the product. This is achieved by reducing the cost, due to the replacement of natural aggregate by the recycled one, IOT, and increasing the esteem value. The SCT's emotional/esteem value is related to the historical, architectural and artistic values of cement tiles, as well as the satisfaction provided to the consumer, who, when acquiring the product, contributes to the recycling of waste. On the assumption that the replacement of natural aggregate by IOT does not change the value in use of SCT, i.e. they have compatible technical aspects, we can summarize these considerations in the following equation:

$\Delta V=V e-V c$

Eq. 4
That is, reducing the cost of production and/or increasing the esteem value of cement tiles lead to higher profits.

\section{Epathymap}

The Empathy Map assists on the understanding of the environment, behaviour, concerns, and aspirations that affect the users of a product (TSCHIMMEL, 2012). This method assists the design process based on the client perspectives, through a defined template and guide questions, displayed in Table 2 (OSTERWALDER; PIGNEUR, 2013). The empathy map in the present work was drawn based on personas representing one professional in interior design and one potential consumer. These hypothetical archetypes of real users were evaluated in order to identify influences, needs, emotions and fears, related to the context of the SCT (FERREIRA et al., 2015; ACUÑA; CASTRO; JURISTO, 2012). This tool has obtained excellent results in product development processes (RIBEIRO; SOUZA, 2014). In the present work, the user modelling technique served as a guide to understanding the intangible values associated with the SCT, through ideological mapping of feelings, thoughts, concerns and aspirations of potential consumers for the product.

Table 2- Questions for developing the empathy map

\begin{tabular}{|c|c|}
\hline Field & Guiding Questions \\
\hline \multirow{12}{*}{ Do } & What is common for him/her to say? \\
\hline & How does s/he normally act? \\
\hline & What are his/her hobbies? \\
\hline & What does he like to say? \\
\hline & How is the world in which s/he lives? \\
\hline & What do people around him/her do? \\
\hline & Who are his/her friends? \\
\hline & What is popular in his daily life? \\
\hline & What people and ideas influence him/her? \\
\hline & What do the important people in his/her life say? \\
\hline & What are his/her favourite brands? \\
\hline & Who are his/her idols? \\
\hline Think & What are some important ideas that s/he thinks and does not say? \\
\hline \multirow{2}{*}{ Feel } & How does s/he feel about life? \\
\hline & What bothers him/her lately? Why? \\
\hline \multirow{4}{*}{ Pains } & What is s/he afraid of? \\
\hline & What are his/her frustrations? \\
\hline & What has disturbed him? \\
\hline & What would s/he like to change in his/her life? \\
\hline \multirow{5}{*}{ Needs } & What does s/he need to feel better? \\
\hline & What is success? What does s/he want to achieve? \\
\hline & What has s/he done to be happy? \\
\hline & What would end his/her pain? \\
\hline & What are some of his/her dreams? \\
\hline
\end{tabular}

Source: Osterwalder and Pigneur (2013). 


\section{Surface design}

By relating the results of the Empathy Map, the colour range of IOT and a thorough investigation of the history of cement tiles, four design proposals were developed. They embrace shape, colour palette and illustration of the colour layer, seeking to incorporate value and to facilitate incorporation in the market.

\section{Results and discussion}

\section{Technical Feasibility}

According to Brazilian standard NBR 9457 (ABNT, 2013), aggregates for cement tiles may be natural, industrial or recycled. Therefore, the use of IOT as recycled aggregate is within the prescriptions of the standard.

Figure 3 shows the particle size distribution of the materials. The characteristic dimensions, D10, D50 e D90 can be seen in Table 3 (where DN corresponds to the diameter of the sieve, in $\mathrm{mm}$, above which N\% passed). It is noticeable that the $\mathrm{CP}$ is a particularly fine material, with $90 \%$ of its particles smaller than $8 \mu \mathrm{m}$. It is followed by the P-IOT, with $90 \%$ of the material smaller than 0.06 $\mathrm{mm}$; IOT (0.17 mm); CWM (0.7 mm), and natural fine aggregate, river sand, with D90 of $1.8 \mathrm{~mm}$.
The particle size distributions of IOT and CWM are not within the optimum limits of aggregates for cement-base composites prescribed by Brazilian standard NBR 7211 (ABNT, 2009), due to their fineness. The small particle size distribution of the IOT may lead to an increase of the amount of water to obtain workability for the matrix, as is commonly observed for conventional pigments (BRUCE; ROWE, 1992). This effect will be probably more significant for CP. On the other hand, the fineness of the IOT enables it to be used as both pigment and filler on the colour layer, thus reducing the pores and enhancing its aesthetic aspects.

Concerning the microstructure (Figure 4 to Figure 8 the CP SEM predominantly presents fine, subrounded and tabular particles. Most of the P-IOT grains, both large and small, are also sub-rounded, due to the burning process. In the analysis, IOT particles show an irregular morphology, with a large amount of fines. Furthermore, as confirmed by the particle size distribution of the materials, river sand and CWM presented relatively larger particles, with the CWM ones slightly more angular than the others, due to its obtaining process.

Figure 3 - Particle size distribution of the materials

Particle Size (mm)

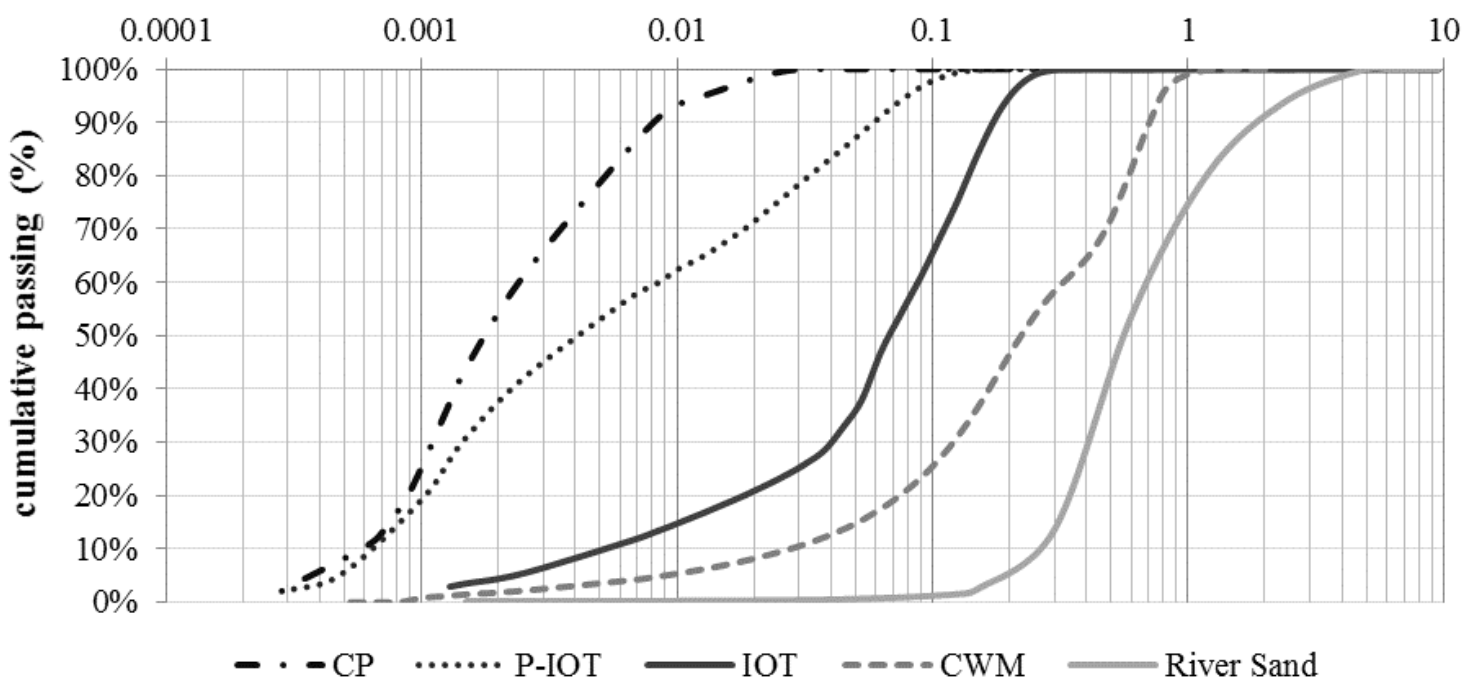

Table 3 - Characteristic dimensions of the materials

\begin{tabular}{l|c|c|c|c|c}
\hline & CP & P-IOT & IOT & CWM & River Sand \\
\hline D10 (mm) & 0.0006 & 0.0003 & 0.0050 & 0.0300 & 0.3000 \\
D50 (mm) & 0.0020 & 0.0020 & 0.0800 & 0.2000 & 0.6000 \\
D90 (mm) & 0.0080 & 0.0580 & 0.1700 & 0.7000 & 1.8000 \\
\hline
\end{tabular}

402 Fontes, W. C.; Fontes, G. G.; Costa, E. C. P.; Mendes, J. C.; Silva, G. J. B. Peixoto, R. A. F. 
Figure 4 - SEM of CP particles $(20,000 x)$

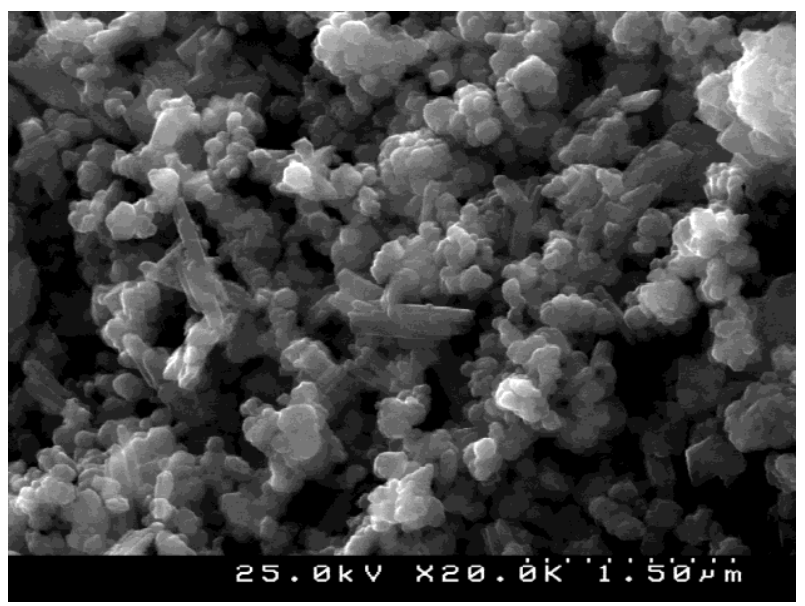

Figure 5 - SEM of P-IOT particles $(20,000 x)$

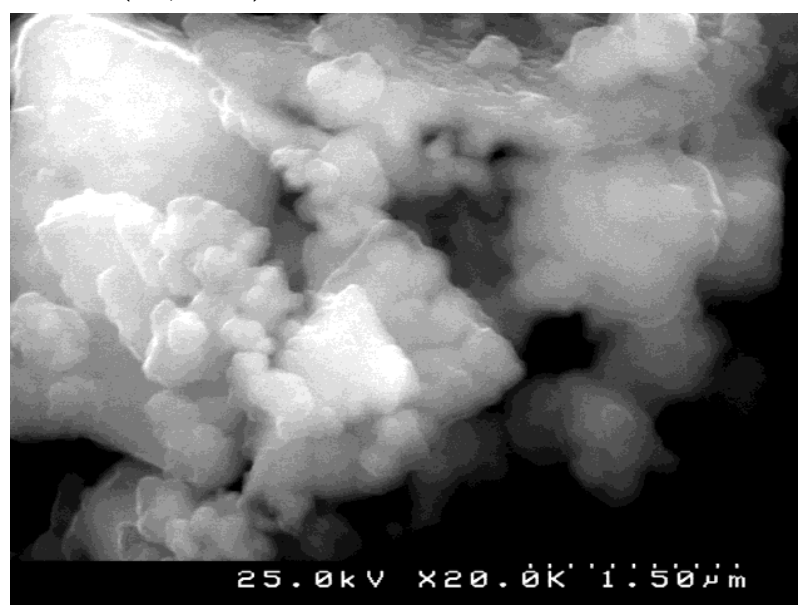

Figure 6 - SEM of IOT particles - 500x

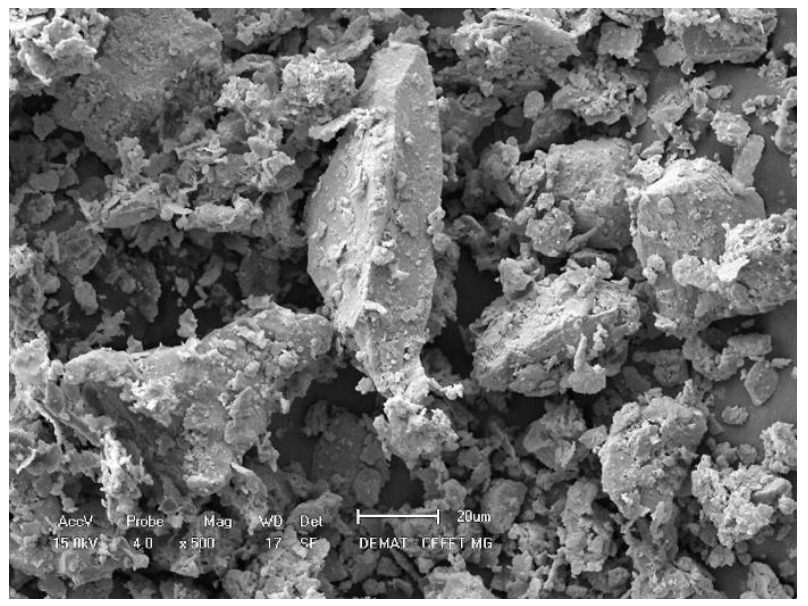


Figure 7- SEM of CWM particles - 200x

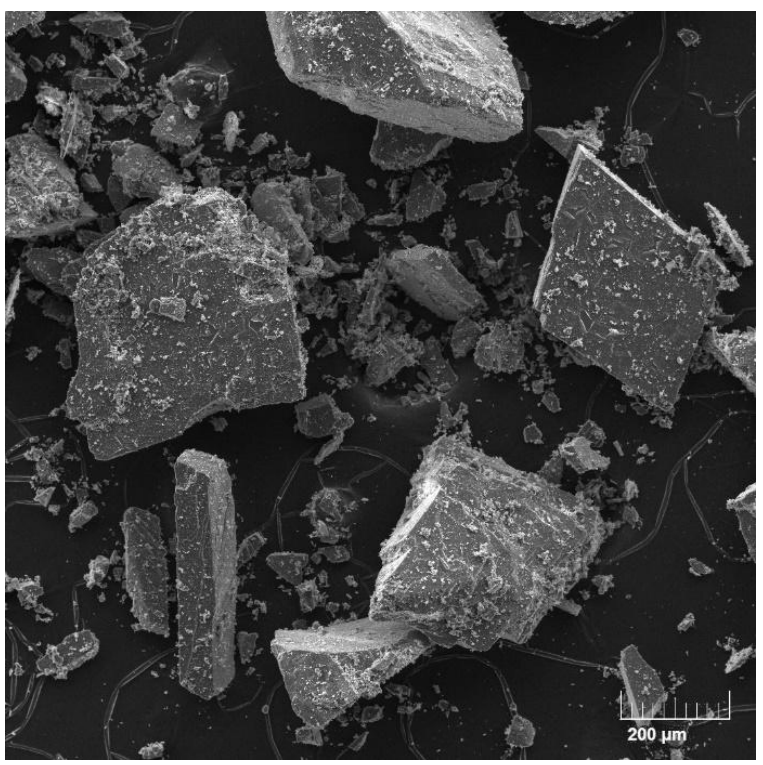

Figure 8 - SEM of River Sand particles - 500x

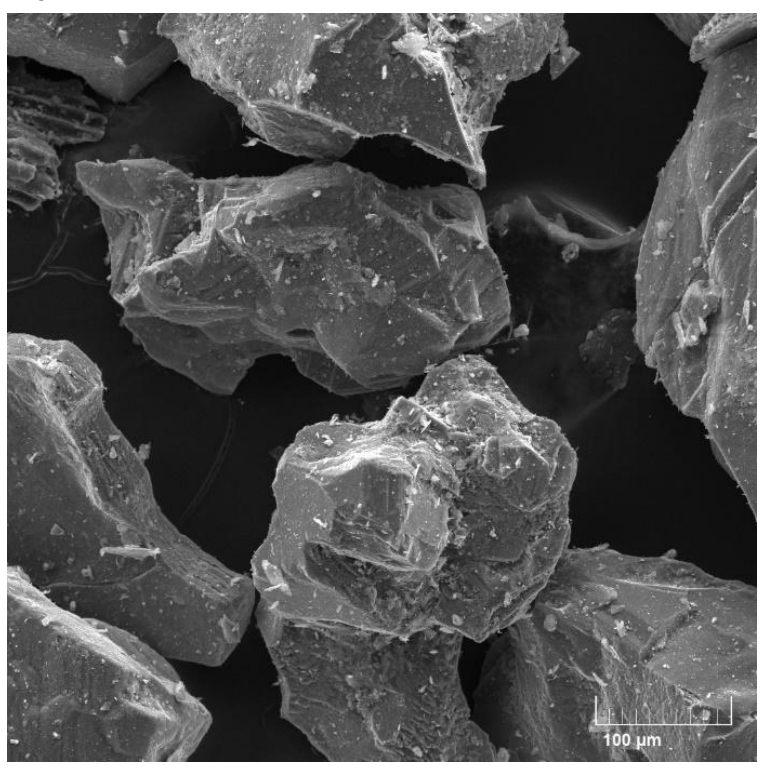

Table 4 shows the physical characterisation of the aggregates and mineral admixtures used in the present work, while Table 5 shows their chemical characterisation. It is observable that the natural aggregate, river sand, showed lower bulk and apparent density when compared to the other aggregates. This is due to their chemical composition.

Regarding the XRF, it is shown that river sand is mainly comprised by silicon and aluminium oxides; iron and silicon oxides are the predominant components of IOT, while calcium and magnesium oxides are the major constituents of CWM.
Figure 9 shows the diffractogram of the IOT sample, with the main components highlighted in the curves: quartz, hematite and kaolinite. Therefore, the XRF and DRF analysis combined showed no deleterious or expansive substances in significant concentration, such as chlorites and sulphates (ABNT, 2009).

As a result of the physical and chemical characterisation, the IOT is an inorganic, crystalline, innocuous and stable material, and thus a suitable aggregate for cement-based composites, according to the Brazilian standard NBR 7211 (ABNT, 2009). In addition, its fineness improves its usability as pigment and filler in the colour and base layers of the SCT.

404 Fontes, W. C.; Fontes, G. G.; Costa, E. C. P.; Mendes, J. C.; Silva, G. J. B. Peixoto, R. A. F. 
Table 4 - Physical Characterisation of the materials

\begin{tabular}{c|c|c|c|c|c}
\hline & CP & P-IOT & IOT & CWM & River Sand \\
\hline Bulk Density $\left(\mathrm{kg} / \mathrm{m}^{3}\right)$ & 4.26 & 3.88 & 3.37 & 2.88 & 2.69 \\
Apparent Density $\left(\mathrm{kg} / \mathrm{m}^{3}\right)$ & 0.56 & 1.13 & 1.42 & 1.70 & 1.54 \\
\hline
\end{tabular}

Table 5 - Chemical characterisation of the Materials

\begin{tabular}{c|c|c|c|c|c}
\hline & CP (\%) & P-IOT (\%) & IOT (\%) & CWM (\%) & River Sand (\%) \\
\hline $\mathrm{Fe}_{2} \mathrm{O}_{3}$ & 92.2 & 66.6 & 49.0 & 0.2 & 4.7 \\
$\mathrm{SiO}_{2}$ & 0.0 & 12.6 & 40.1 & 3.1 & 59.6 \\
$\mathrm{Al}_{2} \mathrm{O}_{3}$ & 0.0 & 14.9 & 8.9 & 0.0 & 31.3 \\
$\mathrm{~K}_{2} \mathrm{O}$ & 0.0 & 0.2 & 0.3 & 0.0 & 1.7 \\
$\mathrm{TiO}_{2}$ & 0.0 & 0.8 & 0.0 & 0.0 & 1.2 \\
$\mathrm{SO}_{3}$ & 0.5 & 0.3 & 0.1 & 1.0 & 1.0 \\
$\mathrm{CaO}$ & 4.3 & 0.0 & 0.0 & 63.8 & 0.5 \\
$\mathrm{MnO}$ & 2.5 & 0.3 & 0.1 & 0.0 & 0.1 \\
$\mathrm{MgO}$ & 0.0 & 3.6 & 0.4 & 31.8 & 0.0 \\
$\mathrm{ZnO}$ & 0.5 & 0.1 & 0.2 & 0.0 & 0.0 \\
Others & 0.1 & 0.0 & 0.0 & 0.1 & 0.1 \\
\hline
\end{tabular}

Figure 9- DRX diffractogram of IOT

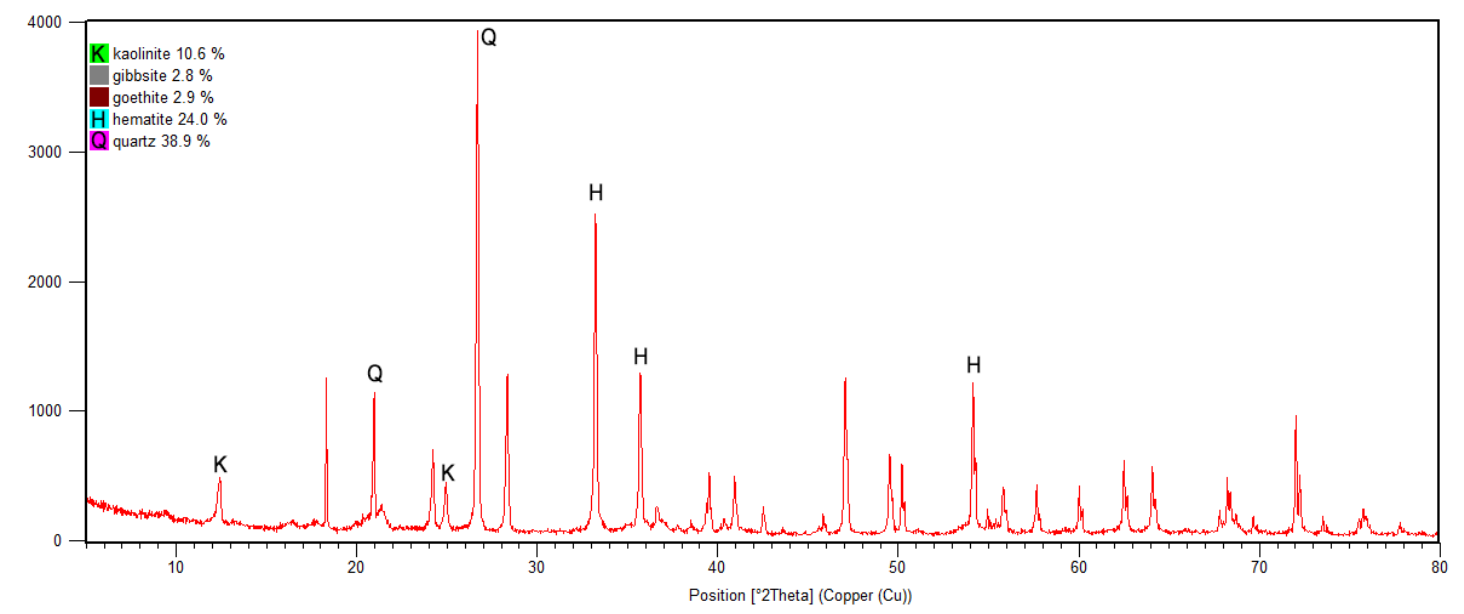

\section{Environmental feasibility}

The leaching and dissolution analyses performed for the IOT confirm their environmental feasibility. The results for the dissolution parameters that exceeded the normative requirement are presented in Table 6. For the leaching test, the IOT presented all results within the standard limits. According to the prescriptions of standard NBR 10004 (ABNT, 2004c), the samples were classified as Class II A, nondangerous and non-inert. Thus, it does not present hazardous characteristics such as corrosivity, reactivity, toxicity, pathogenicity or flammability (ABNT, 2004c).

\section{Feasibility as pigment}

The colour layer compositions, with IOT and conventional, are shown in Figure 10. The specimens showed a comprehensive variety of tones, sharp edges and a homogeneous surface no cracks, burrs or flaws were observed. This appearance is in accordance with the visual inspection prescribed by standard (ABNT, 2013).

In mixtures $\mathrm{T} 1, \mathrm{~T} 2$ and $\mathrm{T} 3$, with increase in content of IOT as aggregate, a darker reddish/brownish tone was achieved (Figure 10a). In mixtures T6 and T7 (Figure 10b), in comparison with the same content of conventional colorant T4 and T5 - the IOT showed slightly lower pigment properties. Mixtures with P-IOT, T8 and T9, showed better performance than those with the in natura IOT, but with colours not as dark as the ones with $\mathrm{CP}$. These observations are related to the lower iron content in the IOT than in the CP. However, the lightness of tones be corrected, if wished, with an increase in IOT content, which is also more sustainable. The ones with double 
colours showed overall good contrast and did not present mixing, as shown in Figure 10c. Mixtures with IOT, as shown on the left of Figure 11, presented less pores, with reduced size, in comparison with conventional ones, on Figure 11right. This is a result of the filler effect of the IOT, as shown in its particle size distribution.

This result is in agreement with the works of Sant'Ana et al. (2016), whose cement-based composites presented homogeneous colours and less pores than the conventional counterparts. In addition, the colour does not fade or stain, as observed in the work of Fontes et al. (2016), whose coating mortars were subjected to the outdoors environment for over 3 years and showed no alteration on their surface quality.

Table 6 - Dissolution results for the raw IOT that exceeded the standard requirements

\begin{tabular}{c|c|c}
\hline Chemical elements & Average concentration (mg/L) & Upper limit (mg/L) \\
\hline Aluminum & 0.38 & 0.2 \\
Phenols & 0.53 & $\mathrm{NA}$ \\
Iron & 1.038 & 0.3 \\
\hline
\end{tabular}

Figure 10 - Colour layer mixtures: T1, T2 and T3 comprise $0 \%, 25 \%$ and $50 \%$ of IOT as aggregate; in T4 and T5 use CP as pigment, T6 and T7, IOT and T8 and T9, P-IOT; finally, T10 and T11 present double colours with $\mathrm{CP}$ and $\mathrm{P}-\mathrm{IOT}$ respectively
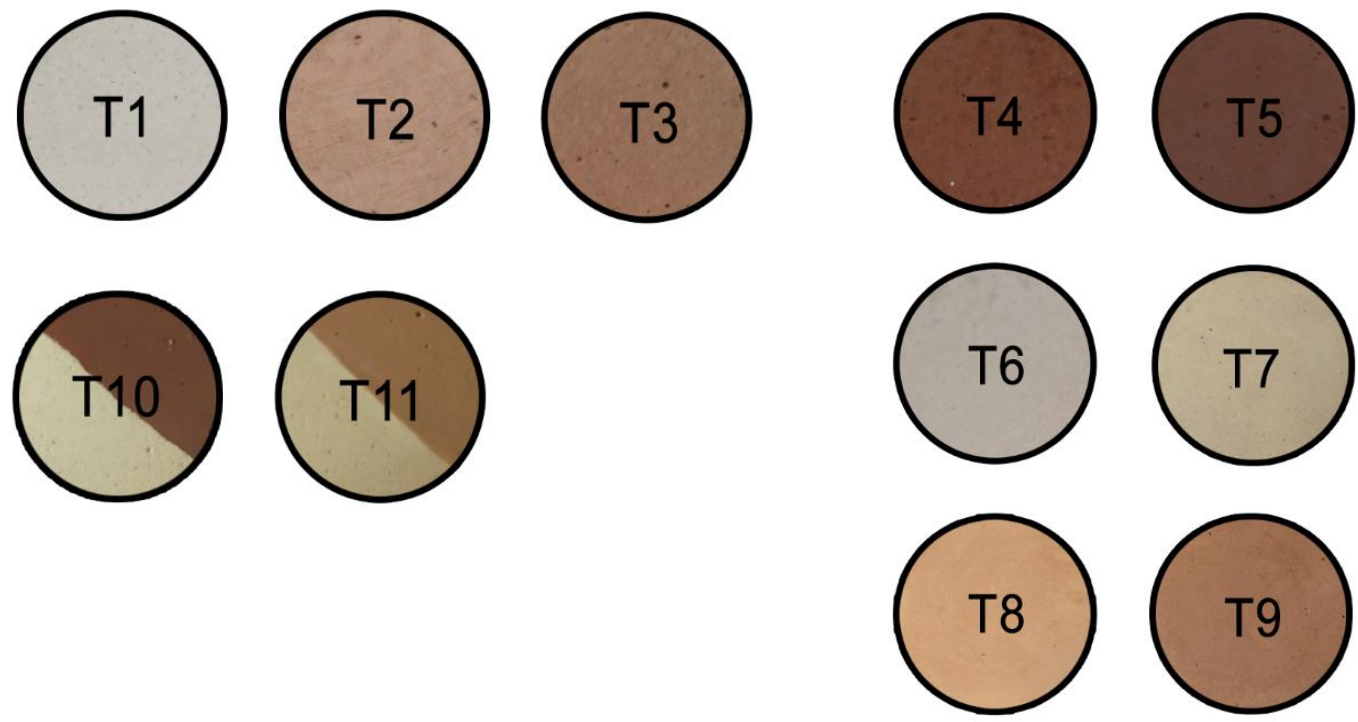

Figure 11 - Surface of mixtures T5 (left) and T7 (right), magnification 10x
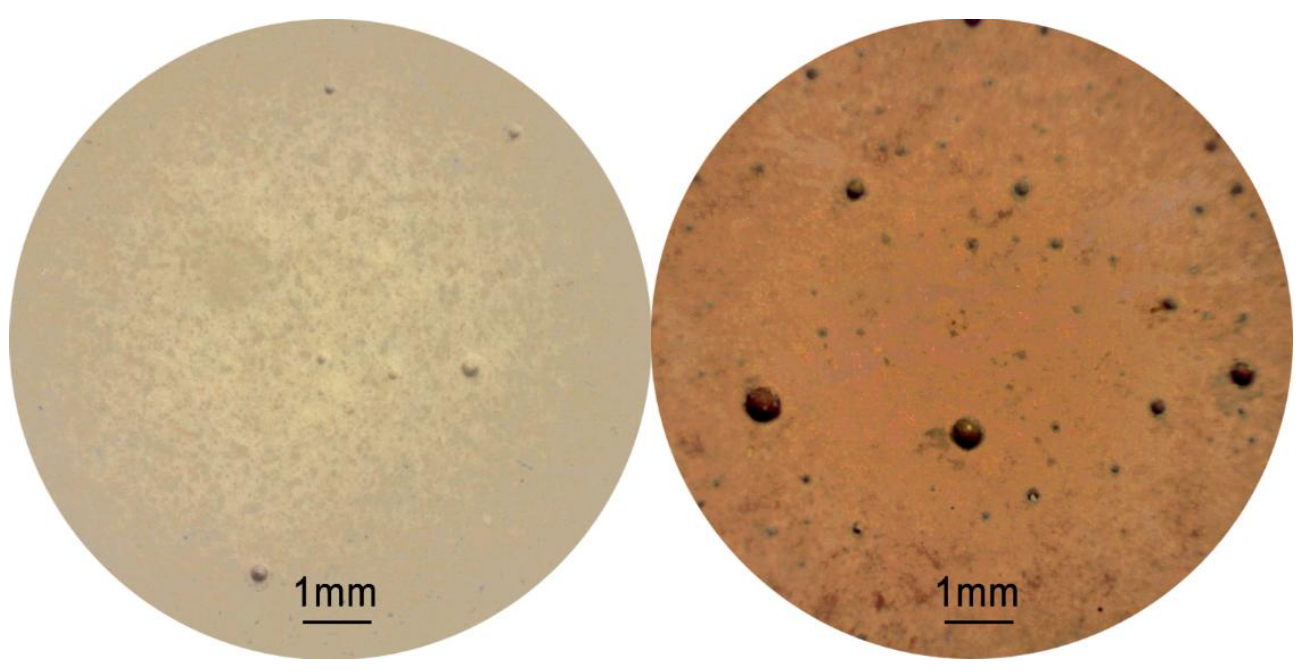

406 Fontes, W. C.; Fontes, G. G.; Costa, E. C. P.; Mendes, J. C.; Silva, G. J. B. Peixoto, R. A. F. 


\section{Value analysis}

\section{Empathy map}

From the studies carried out, the design is presented as a fundamental tool in the conception of a link between product and user. Thus, Figures 12 and 13 seek to trace a consumer profile for the SCT, by considering the perspective of customers, fulfilling their needs.

\section{Environmental, social and esteem assessments}

In Brazil, the cement tile is responsible for creating new dimensions of the art, while acquiring national traits (WAMZER, 2011). Thus, it associated uniqueness, personal aspirations and experiences, which constituted an identity to the coating, instigating, therefore, memories and feelings in its users. Thus, this type of coating assumes an affective value able to provide wellbeing and pleasure when used. Furthermore, its craft process has survived in the midst of the massproduced coatings industry.

As a result of the research, SCT prototype will be produced monochrome or coloured at up to five shades. Allied to the colours, the designs applied to the SCT will be traditional, like arabesques, floral and geometric shapes, inspired by elements that reflect local identity. Figure 14shows the surface design of the prototypes of the SCT, based on the value analysis.

The proposed SCT will also use sustainability as an intangible asset, by employing a residue in its composition. The IOT will be employed as aggregate and filler, increasing the physicalmechanical performance of the base layer. Furthermore, it will also be used as colorant in the composition of earthy tones on the colour side.

Figure 12 - Empathy Map of a persona of a SCT consumer: end user

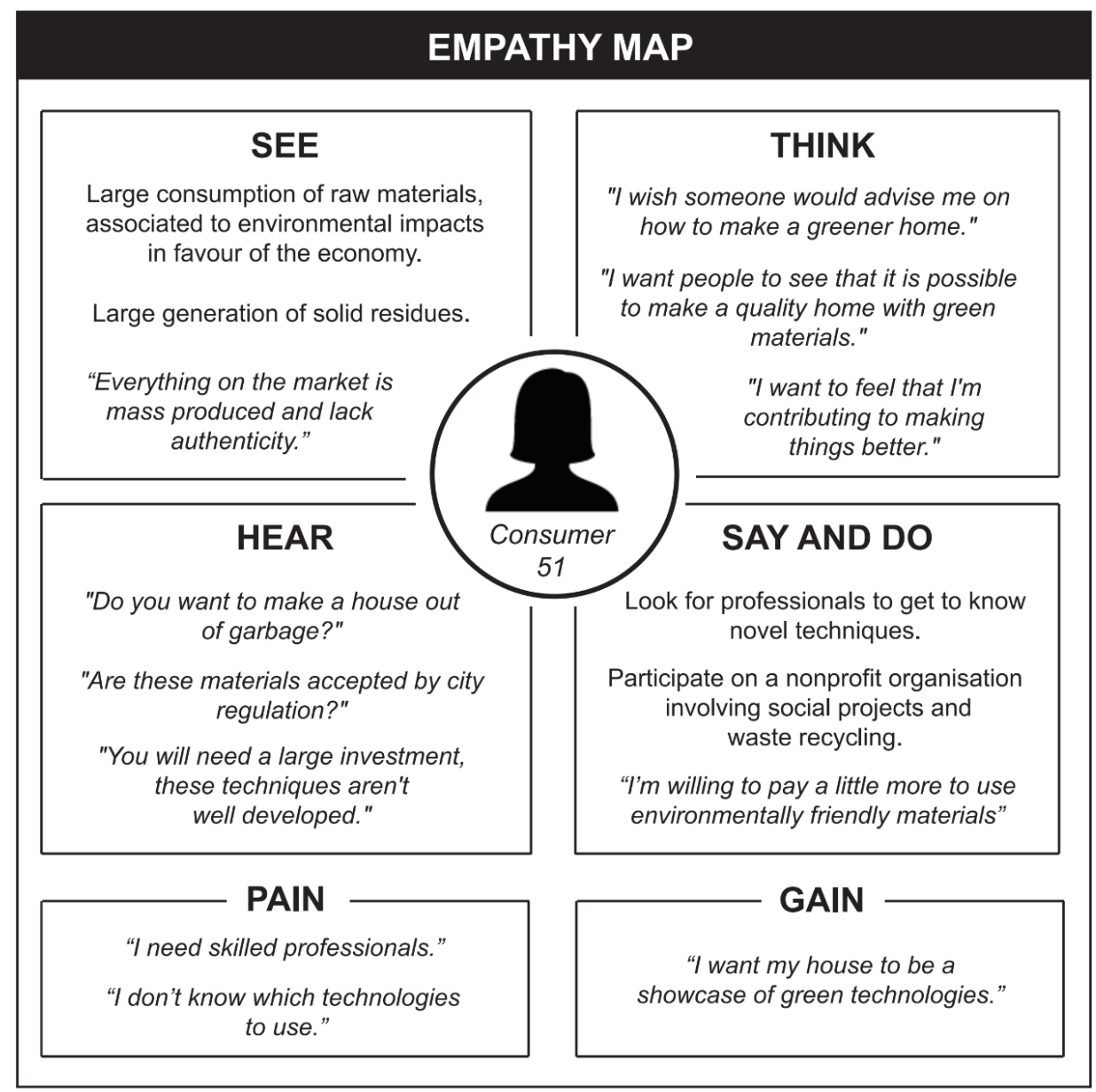


Figure 13 - Empathy Map of a persona of a SCT consumer: interior designer

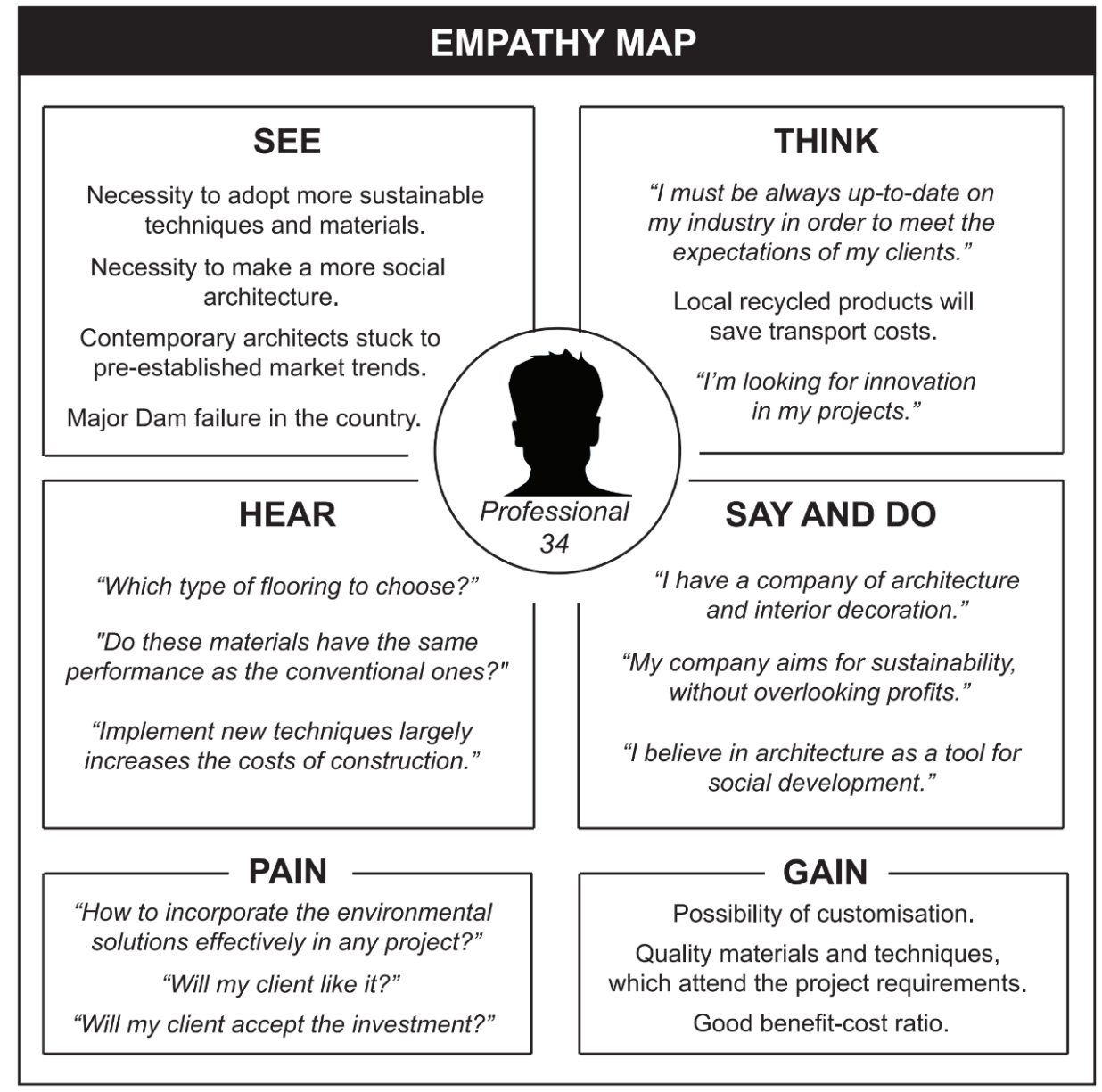

Figure 14 - Surface design of the prototypes of the SCT, based on the value analysis and colour palette
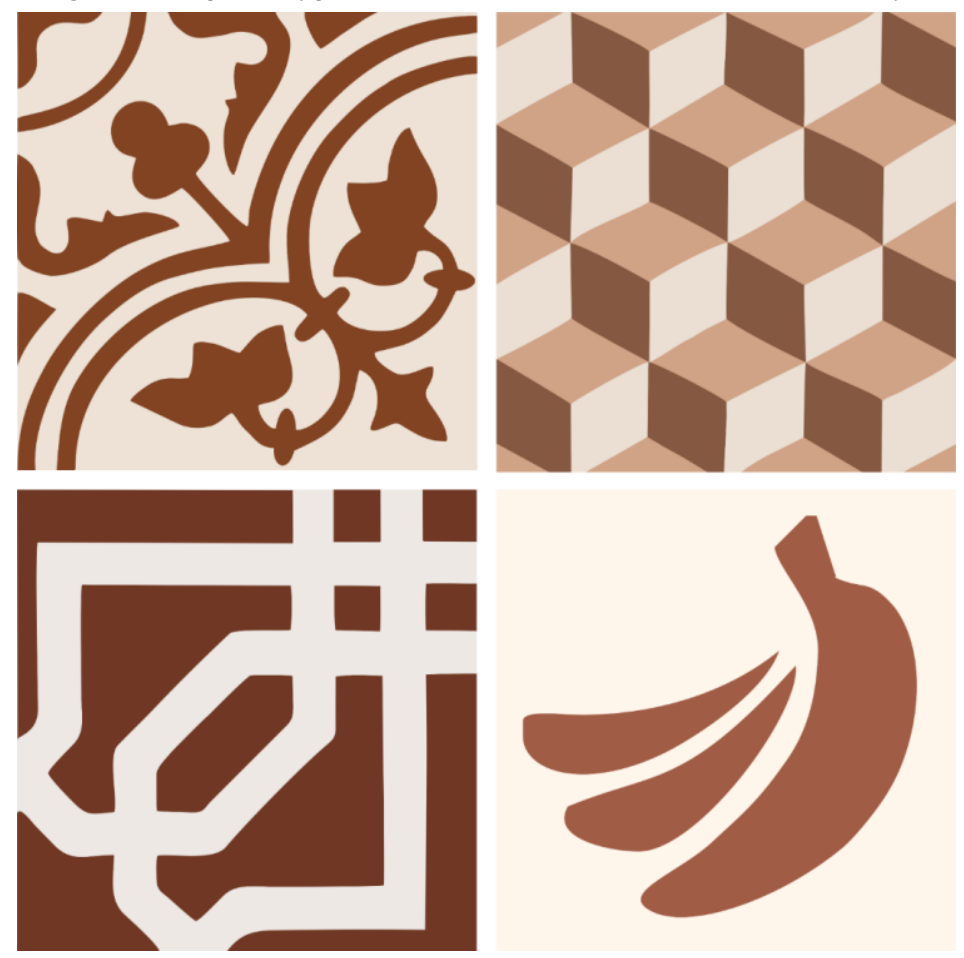

408 Fontes, W. C.; Fontes, G. G.; Costa, E. C. P.; Mendes, J. C.; Silva, G. J. B. Peixoto, R. A. F. 
Regarding the shape, SCT will adopt the most common option, with dimensions of $200 \times 200 \mathrm{~mm}$ and thickness of $25 \mathrm{~mm}$, for ease of insertion of the market. According to the results of Empathy Map, the SCT has the potential to cover both consumers with high income, seeking for social and environmental expression, as the low-income ones, due to nostalgia aspects.

Thus, this type of coating assumes an affective value able to provide well-being when used. Its craft process has survived in the midst of the massproduced industry, promoting labour opportunities for community craftsmen, and strengthening of the culture and local economies. In this sense, the SCT will not only contribute to the reduction of the environmental impact of IOT, but also minimize the costs with raw material, promote new business opportunities for artisans, meet the sustainability agenda of companies, and ultimately improve the quality of the built environment.

\section{Conclusion}

According to the physical, chemical and morphological analysis, iron ore tailings (IOT) are a stable fine material. The environmental tests resulted in a non-dangerous classification, meaning that IOT do not present hazardous characteristics such as corrosivity, reactivity, toxicity, pathogenicity or flammability. Therefore, it is technically and environmentally suitable to be used as replacement of conventional colorant and crushed marble in the colour layer; and as replacement of sand and/or filler in the base layer. In this sense, IOT present a suitable alternative for the production of sustainable cement tiles, producing an aesthetically pleasing and potentially durable coating.

The design proposed for SCT meets the consumers' expectations regardingtheir desires for sustainability, ideology, social expression, nostalgia, among others. It does so by creating a product with local identity, incorporating residues in its manufacture, reducing the impacts of the disposal of IOT, promoting labour opportunities for artisans, strengthening local culture and overall improving the quality of the built environment.

Further investigation is required in order to evaluate the physical and mechanical properties of the Sustainable Cement Tile itself. However, this initial study concludes that the IOT is a technical, social and environmentally feasible alternative to the exploitation of natural resources in the production of cement-based composites. This reuse also contributes to the reduction of risks, and social and environmental impacts of tailings dams.

\section{References}

ACUÑA, S. T.; CASTRO, J. W.; JURISTO, N. A

HCI Technique For Improving Requirementes

Elicitation. Information and Software

Technology, v. 54, n. 12, p. 1357-1375, 2012

ANDRADE, L. C. R. Characterization of Iron

Mining Tailings, in Natura and Segregated, For Use as Construction Material. Universidade

Federal de Viçosa, (Doctoral dissertation), Viçosa, 2014.

\section{ASSOCIAÇÃO BRASILEIRA DE CIMENTO PORTLAND. Cement Tile Manual: public sidewalk. São Paulo, 2010.}

\section{ASSOCIAÇÃO BRASILEIRA DE NORMAS \\ TÉCNICAS. NBR 7217: aggregates:}

determination of particle size distribution. Rio de Janeiro, 1987.

\section{ASSOCIAÇÃO BRASILEIRA DE NORMAS TÉCNICAS. NBR NM 53: coarse aggregate: determination of the bulk specific gravity, apparent specific gravity and water absorption. Rio de Janeiro, 2003.}

\section{ASSOCIAÇÃO BRASILEIRA DE NORMAS}

TÉCNICAS. NBR 10005: procedure for obtention leaching extract of solid wastes. Rio de Janeiro, 2004a.

\section{ASSOCIAÇÃO BRASILEIRA DE NORMAS}

TÉCNICAS. NBR 10006: procedure for obtention of solubilized extraction of solid wastes. Rio de Janeiro, 2004b.

\section{ASSOCIAÇÃO BRASILEIRA DE NORMAS TÉCNICAS.NBR 10004: solid waste:} classification. Rio de Janeiro. 2004c.

\section{ASSOCIAÇÃO BRASILEIRA DE NORMAS TÉCNICAS. NBR NM 45: aggregates:} determination of the unit weight and air-void contents.Rio de Janeiro, 2006.

\section{ASSOCIAÇÃO BRASILEIRA DE NORMAS}

TÉCNICAS. NBR 7211: aggregates: specification. Rio de Janeiro, 2009.

\section{ASSOCIAÇÃO BRASILEIRA DE NORMAS}

TÉCNICAS. NBR 9457: hydraulic tiles to paving: specification and test methods. Rio de Janeiro, 2013.

BASTOS, L. A. C. et al. Using Iron Ore Tailings From Tailing Dams as Road Material. Journalof Materials in Civil Engineering, Ouro Preto, v. 28, n. 10, 2016. 
BRUCE, S. M.; ROWE, G. H. The Influence of Pigments on Mix Designs For Block Paving Units. In: INTERNATIONAL CONFERENCE OF CONCRETE BLOCK PAVING, Auckland, 1992. Proceedings... Auckland, 1992.

CATOIA, T. High Performance Hydaulic Tiles and Coverings. 133 p. Universidade de São Paulo (Master Thesis) São Carlos. 2007.

CHENG, Y. et al. Test Research on the Effects of Mechanochemically Activated Iron Tailings on the Compressive Strength of Concrete. Construction an Building Materials, v. 118, p. 164-170, 2016.

CREUSEN, M. E.; SCHOORMANS, J. P. The Diferent Roles of Product Appearance in Consumer Choice. Journal of Product Innovation Management, v. 22, n. 1, p. 63-81, 2005.

CSILlAG, J. M. Value Analysis. São Paulo: Atlas, 1995.

DUAN, P. et al. Fresh Properties, Compressive Strength and Microstructure of Fly Ash Geopolymer Paste Blended With Iron Ore Tailing Under Thermal Cycle. Construction and Building Materials, v. 118, p. 76-88, 2016.

EDRAKI, M. et al. Designing Mine Tailings For Better Environmental, Social and Economic Outcomes: a rewiew of alternative approaches. Journal of Cleaner Production, v. 84, p. 411420, 1 Dec. 2014.

ESTY, D.; WINSTON, A. Green to Gold: how smart companies use environmental strategy to innovate, create value, and build competitive advantage. New York: John Wiley \& Sons, 2009.

FUNDAÇÃO ESTADUAL DO MEIO AMBIENTE. Inventário de Barragens de Minas Gerais: ano 2014. Belo Horizonte, 2014.

FERREIRA, B. M. et al. Designing Personas With Empathy Map.In:INTERNATIONAL CONFERENCE ON SOFTWARE ENGINEERING AND KNOWLEDGE ENGINEERING, Pittsburgh, 2015.Proceedings... Pittsburgh, 2015.

FIGUEIRÔA, S. Mining in Brazil. In: SELIN, H. (Ed.).Encyclopedia of the History of Science, Technology, and Medicine in Non-Western Cultures.Amsterdam: Springer, 2014.

FONTES, W. C. et al.Mortars For Laying and Coating Produced With Iron Ore Tailings From Tailing Dams. Construction and Building Materials, v. 112, 2016.
FRANKS, D. M. et al. Sustainable Development Principles For the Disposal of Mining and Mineral Processing Wastes. Resources Policy, v. 36, p. 114-122, 2011.

\section{G1. Tailings From Dams Reach Areas Up to} 100km in MG. 2015. Available:

<http://g1.globo.com/minasgerais/noticia/2015/11/hidreletrica-100-km-eafetada-por-lama-do-rompimento-debarragens.html>. Access: 20 November 2015.

GONTIJO, L. A. Complexity and Interdisciplinarity in Interface Design. Advanced Studies in Design: Transversality, v. 1, n. n. 2, p. 79-90, 2008.

\section{INSTITUTO BRASILEIRO DE MUSEUS.} Management for Sustainability in Mining: 20 years of history. Brasília, 2013.

INSTITUTO BRASILEIRO DE MUSEUS. Information on the Mineral Economy of the State of Minas Gerais. Brasília, 2014.

INSTITUTO BRASILEIRO DE MUSEUS. Information Regarding the Brazilian Mining Economics. Brasília, 2015.

JORDAN, P. Inclusive Design.In: GREEN, W. S.; JORDAN, P. W. (Eds.). Human Factors in Product Design: current practice and future trends. London:CRC Press, 1999.

\section{KISSMETRICS, B. How Do Colors Affect}

Purchases? 2010. Available:

<https://blog.kissmetrics.com/colors-psycology/>. Access: 22 June 2016.

LEDOUX, J. The Emotional Brain: the mysterious underpinnings of emotional life. Simon and Schuster, 1998.

LEE, H. S.; LEE, J. Y.; YU, M. Y. Influence of Iron Oxide Pigments on the Properties of Concrete Interlocking Blocks. Cement and Concrete Research, v. 33, n. 11, p. 1889-1896, 2003.

LUCKY IRON FISH. About Us. 2016. Available: <http://www.luckyironfish.com/about-us>. Access: 22 June 2016.

MA, B. G. et al. Utilization of Iron Tailings as Subtitute in Autoclaved Aerated Concrete: physico-mechanical and microstructure of hydration products. Journal of Cleaner Production, v. 127, p. 162-171, 2016.

MIRANDA, C. A.; CÂMARA, J. J. D. Origin, Culture and Value Analysis in Design of Products From Plastic Bottles. In:BRAZILIAN CONGRESS OF RESEARCH AND DEVELOPMENT DESIGN, 9., 2010. Proceedings... 2010. 
MORAES, D. Design and Complexity. Advanced Studies in Design: Transversality, v. 1, n.2, p. 723, 2008.

OBSERVATORY, B. I.Smart Living: advanced building materials. European Union, 2014.

OSTERWALDER, A.; PIGNEUR, Y. Business

Model Generation. São Paulo: Alta Books, 2013.

PAPPU, A.; SAXENA, M.; ASOLEKAR, S. R. Solid Wastes Generation in India and Their Recycling Potential in Building Materials. Building and Environmental, v. 42, p. 23112320, 2007.

PASSUELLO, A. C. B. et al.Aplicação da Avaliação do Ciclo de Vida na Análise de Impactos Ambientais de Materiais de Construção Inovadores: estudo de caso da pegada de carbono de clíqueres alternativos. Ambiente Construído, Porto Alegre, v. 14, n. 4, p. 7-20, out./dez. 2014.

PEIXOTO, R. A. F.; BARROS, J. B.; OLIVEIRA, J. R. Processo de Extração de Argila, Sílica e Minério de Ferro Através de Concentração a Seco. Patent Pending - BR 102014002076 4, 2014.

PEREIRA FILHO, R. R. Value Analysis: continuos improvement process. São Paulo: Nobel, 1994.

PEREIRA, O. C.; BERNARDIN, A. M. Ceramic Colorant Form Untreated Iron Ore Residue. Journal of Hazardous Materials, v. 233-234, p. 103-111, 2012.

RIBEIRO, T.; SOUZA, P. A Study on the Use of Personas as an Usability Evaluation Method. In:INTERNATIONAL CONFENRENCE ON ENTERPRISE INFORMATION SYSTEMS, 16., Lisbon, 2014. Proceedings... Lisbon, 2014.

RUSCHEL, R. R.; ROSE, R. E. The Path of Sustainable Development: the memory of the first 5 years of the Von Martius Environmental Award. AHK, Câmara Brasil Alemanha, 2005.

SANT'ANA FILHO, J. N. et al. Technical and Environmental Feasibility of Interlocking Concrete Pavers with Iron Ore Tailings from Tailings Dams. Journal of Materials in Civil Engineering, v. 29, n. 9, p. 04017104, 2016.
SHETTIMA, A. U. et al. Evaluation of Iron Ore Tailing as Replacement For Fine Aggregate in Concrete. Construction and Building Materials, v. 120, p. 72-79, 2016.

TAVARES, P. H. C. P. Obtenção de Pigmentos de Óxido de Ferro a Partir da Lama Gerada no Beneficiamento de Itabirito.Ouro Preto, 2012. $\mathrm{PhD}$ Thesis - Universidade Federal de Ouro Preto, Ouro Preto, 2012.

TSCHIMMEL, K. Design Thinking as an Effective Toolkit for Innovation. In: ISPIM, 23., Barcelona, 2012. Proceedings... Barcelona, 2012.

VARGAS, R. V. Earned Value Analysis.

Brasport, n. 6, p. 144, 2013.

WAMZER, R. L. K. The Cement Tile in Interface With art and Design in Mato Grosso. Universidade Federal do Mato Grosso (Masters Thesis). Cuiabá, 2011.

WILLARD, B. The Sustainability Advantage: sever business case benefits of a triple bottom line.[S.1.]: New Society Publishers,2002.

YELLISHETTY, M. et al. Reuse of Iron Ore Mineral Wastes in Civil Engineering Constructions: a case study.

Resources,Conservation and Recycling, v. 52, p. 1283-1289, 2008.

ZHAO, S.; FAN, J.; SUN, W. Utilization of Iron ore Tailings as Fine Aggregate in Ultra-High Performance Concrete. Construction and Building Materials, v. 50, p. 540-548, 2016.

\section{Acknowledgments}

We gratefully acknowledge the agencies FAPEMIG, CNPq, CAPES, UFOP and Fundação Gorceix for providing financial support. We are also grateful for the infrastructure and collaboration of the Research Group on Solid Wastes - RECICLOS - CNPq.

The authors would like to acknowledge the Nanolab Electronic Microscopy Laboratory, at the Redemat, UFOP; the Department of Ceramic and Glass Engineering from Universidade de Aveiro and the Materials Characterisation Laboratory, at CEFET, MG, Brazil, for providing the equipment and technical support for electron microscopy. 


\section{Wanna Carvalho Fontes}

Programa de Pós-Graduação em Engenharia Civil | Universidade Federal de Ouro Preto | Campus Morro do Cruzeiro | Ouro Preto - MG Brasil | CEP 35400-000 | Tel.: (31) 3559-1547 | E-mail: wannarquit@gmail.com

\section{Giovanni Gonçalves Fontes}

Programa de Pós-Graduação em História da Arte | Faculdade Dom Luciano Mendes | Rodovia dos Inconfidentes, Km 108, Mariana - MG Brasil | CEP 35420-000 | Tel.: (31) 3558-1439 | E-mail: gigiogf@gmail.com

\section{Ellen Cristine Pinto Costa}

Departamento de Arquitetura | Universidade Federal de Ouro Preto | Campus Morro do Cruzeiro | Ouro Preto - MG - Brasil | CEP 35400 000 | Tel.: (31) 3559-1484 | E-mail: ellencosta425@gmail.com

\section{Julia Castro Mendes}

Departamento de Engenharia Civil | Universidade Federal de Ouro Preto | Tel.: (31) 3559-1546 | E-mail: jcmendes.eng@gmail.com

Guilherme Jorge Brigolini Silva

Departamento de Engenharia Civil | Universidade Federal de Ouro Preto | E-mail: guilhermebrigolini@gmail.com

\section{Ricardo André Fiorotti Peixoto}

Departamento de Engenharia Civil | Universidade Federal de Ouro Preto | E-mail: ricardo.fiorotti@ufop.edu.br

\section{Revista Ambiente Construído}

Associação Nacional de Tecnologia do Ambiente Construído

Av. Osvaldo Aranha, $99-3^{\circ}$ andar, Centro

Porto Alegre - RS - Brasil

$$
\text { CEP } 90035-190
$$

Telefone: +55 (51) 3308-4084

Fax: +55 (51) 3308-4054

www.seer.ufrgs.br/ambienteconstruido

E-mail: ambienteconstruido@ufrgs.br 